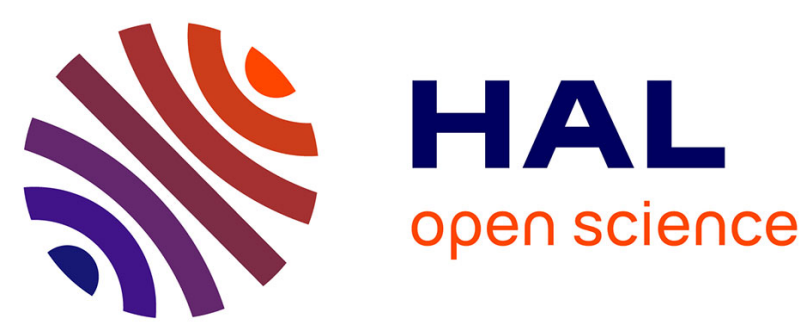

\title{
Geology, biostratigraphy and carbon isotope chemostratigraphy of the Palaeogene fossil-bearing Dakhla sections, southwestern Moroccan Sahara
}

Mouloud Benammi, Sylvain Adnet, Laurent Marivaux, Johan Yans, Corentin Noiret, Rodolphe Tabuce, Jérôme Surault, Imad El Kati, Sebastien Enault, Lahssen Baidder, et al.

\section{To cite this version:}

Mouloud Benammi, Sylvain Adnet, Laurent Marivaux, Johan Yans, Corentin Noiret, et al.. Geology, biostratigraphy and carbon isotope chemostratigraphy of the Palaeogene fossil-bearing Dakhla sections, southwestern Moroccan Sahara. Geological Magazine, 2019, 156 (1), pp.117-132. 10.1017/S0016756817000851 . hal-01813156

\section{HAL Id: hal-01813156 \\ https://hal.umontpellier.fr/hal-01813156}

Submitted on 1 Nov 2020

HAL is a multi-disciplinary open access archive for the deposit and dissemination of scientific research documents, whether they are published or not. The documents may come from teaching and research institutions in France or abroad, or from public or private research centers.
L'archive ouverte pluridisciplinaire HAL, est destinée au dépôt et à la diffusion de documents scientifiques de niveau recherche, publiés ou non, émanant des établissements d'enseignement et de recherche français ou étrangers, des laboratoires publics ou privés. 


\section{Geology, biostratigraphy and carbon isotope chemostratigraphy of the Paleogene fossil-bearing Dakhla sections, Southwestern Moroccan Sahara}

\begin{tabular}{|r|l|}
\hline Journal: & Geological Magazine \\
\hline Manuscript ID & GEO-17-1733.R1 \\
\hline Manuscript Type: & Review Article \\
\hline Date Submitted by the Author: & n/a \\
\hline Complete List of Authors: & $\begin{array}{l}\text { benammi, mouloud; Universite de Poitiers UFR Sciences Fondamentales et } \\
\text { Appliquees, Institut de Paléoprimatologie et Paléontologie humaine: } \\
\text { Evolution et Paléoenvironnements - iPHEP CNRS UMR 7262 } \\
\text { Adnet, Sylvain; Universite de Montpellier, 2Institut des Sciences de } \\
\text { I'Evolution de Montpellier (ISE-M), UMR 5554 CNRS/UM/IRD/EPHE } \\
\text { Marivaux, Laurent; Universite de Montpellier, 2Institut des Sciences de } \\
\text { I'Evolution de Montpellier (ISE-M), UMR 5554 CNRS/UM/IRD/EPHE } \\
\text { Yans, Johan; Universite de Namur, Department of Geology } \\
\text { Noiret, Corentin; Universite de Namur, Department of Geology } \\
\text { Tabuce, rodolphe; Universite de Montpellier, 2Institut des Sciences de } \\
\text { I'Evolution de Montpellier (ISE-M), UMR 5554 CNRS/UM/IRD/EPHE } \\
\text { Surault, Jerome; Universite de Poitiers UFR Sciences Fondamentales et } \\
\text { Appliquees, 1Institut International de Paléoprimatologie, Paléontologie } \\
\text { Humaine: Evolution et Paléoenvironnements (iPHEP), UMR-CNRS 7262 } \\
\text { El Kati, Imad; Universite Ibn Tofail Kenitra, 5Laboratoire de Géologie, } \\
\text { Géophysique, Géorisques et environnement (3GE), Département de } \\
\text { Géologie } \\
\text { Enault, Sebastien; Universite de Montpellier, Institut des Sciences de } \\
\text { I'Evolution de Montpellier (ISE-M), UMR 5554 CNRS/UM/IRD/EPHE } \\
\text { Baidder, Lahcen; Universite Hassan II Casablanca, Laboratoire Géosciences } \\
\text { Saddiqi, Omar; Universite Hassan II Casablanca, Laboratoire Géosciences } \\
\text { Benammi, Mohamed; Universite Ibn Tofail Kenitra, 5Laboratoire de } \\
\text { Géologie, Géophysique, Géorisques et environnement (3GE), Département } \\
\text { de Géologie }\end{array}$ \\
\hline \multirow{2}{*}{$\begin{array}{l}\text { Oligocene, southwestern Morocco, magnetostratigraphy, mammals, } \\
\text { chemostratigraphy, biostratigraphy, rodents }\end{array}$} \\
\hline
\end{tabular}


1 Geology, biostratigraphy and carbon isotope chemostratigraphy of the 2 Paleogene fossil-bearing Dakhla sections, Southwestern Moroccan Sahara 3

4 BENAMMI MOULOUD ${ }^{1}$, ADNET SYLVAIN ${ }^{2}$, MARIVAUX LAURENT $^{2}$, YANS 5 JOHAN $^{3}$, NOIRET CORENTIN ${ }^{3}$, TABUCE RODOLPHE ${ }^{2}$, SURAULT JÉRÔME ${ }^{1}$, EL 6 KATI IMAD ${ }^{5}$, ENAULT SÉBASTIEN ${ }^{2}$, BAIDDER LAHCEN ${ }^{4}$, SADDIQI OMAR $^{4}$, 7 BENAMMI MOHAMED ${ }^{5}$

8

$9 \quad{ }^{1}$ Institut International de Paléoprimatologie, Paléontologie Humaine: Evolution et 10 11 avenue du Recteur Pineau, F-86022 Poitiers cedex, France

$12{ }^{2}$ Institut des Sciences de l'Evolution de Montpellier (ISE-M), UMR 5554

$13 C N R S / U M / I R D / E P H E, C C 064$, Université de Montpellier, place Eugène Bataillon, F-34095

14 Montpellier cedex 05, France

$15{ }^{3}$ Department of Geology, University of Namur, rue de Bruxelles 61, 5000 Namur, Belgium

$16{ }^{4}$ Laboratoire Géosciences, Université Hassan II-Casablanca, BP 5366 Mâ̂rif, Casablanca, 17 Morocco

$18{ }^{5}$ Laboratoire de Géologie, Géophysique, Géorisques et environnement (3GE), Département de 19 Géologie, Université Ibn Tofail, Faculté des Sciences, BP. 133, Kenitra, Morocco 20 
22 Recently new Paleogene vertebrate localities were reported in the southern Dakhla area 23 (southwestern Morocco). The Eocene sediment strata crops out on cliffs along the Atlantic

Ocean coast. Vertebrate remains come from five conglomeratic sandstone beds and are principally represented by isolated teeth belonging to micromammals, selachians and bony fishes, a proboscidean assigned to ?Numidotherium sp., and many remains of archaeocete whales (Basilosauridae). During the fieldwork, five lithostratigraphic sections were described, essentially based on the lithological characteristic of sediments. Despite the lateral variations of facies, correlations between these five sections were possible on the basis of fossil-bearing beds (A1, B1, B2, C1, and C2), and five lithological units were identified. The lower part of the section consists of rhythmically-bedded, chert-rich marine siltstones and marls with thin black phosphorite with organic matter at the base. The overlying units include coarse-grained to microconglomeratic sandstones interbedded with silts, thereby indicating deposition in shallow marine environment with fluvial influence. The natural remanence magnetization of a total of 50 samples was measured, and the intensity of most of the samples is too weak, before or after the first step of demagnetization. The paleomagnetic data of the samples are very unstable, except eight from three similar sandstone levels, which show a normal polarity. Matched with biostratigraphic data on rodents, primates, the selachian, sirenian and cetacean faunas, the new carbon isotope chemostratigraphy on organics 1) refines the age of the uppermost C2 fossil-bearing bed to the earliest Oligocene, and 2) confirms the Priabonian age of the $\mathrm{B} 1$ to $\mathrm{C} 1$ levels.

Keywords: Oligocene, southwestern Morocco, magnetostratigraphy, mammals, chemostratigraphy, biostratigraphy, rodents 


\section{Introduction}

46

47

48

49

50

51

52

\section{7} 8

The study area is in south of Morocco, $60 \mathrm{~km}$ south the coastal town of Dakhla (Fig. 1). This area forms a part of the Tarfaya-Dakhla Basin. It is the southernmost Atlantic basin of Morocco, and extends from the Mauritania border in the south to the Canary Islands in the north. It stretches over more than $1000 \mathrm{~km}$ along the western margin of the Sahara, and covers an area of 170,000 km², both on- and off-shore (Davison, 2005; Sachse et al., 2011, 2014). The geological and stratigraphic structures of the basin have been investigated in detail using well and seismic data (Kolonic et al., 2002, Klingelhoefer et al., 2009 and Davison \& Dailly, 2010). The Tarfaya-Dakhla Basin is filled by Mesozoic and Cenozoic continental to shallowmarine sediments, which overlie the basement Precambrian and/or Paleozoic rocks.

The study area is located in the southern margin of the Tarfaya-Dakhla Basin, between latitude $22^{\circ} 50^{\prime}$ and $24^{\circ} 05^{\prime} \mathrm{N}$; a sector between the gulf of Cintra and N'Tireft village (Fig. 1).

The escarpment exposes Paleogene to Quaternary sediments, which have recently been notable for their abundant and diverse marine and terrestrial faunas, particularly vertebrates (Adnet et al., 2010, Zouhri et al., 2014, Benammi et al., 2014a, 2014b, Marivaux et al., 2017). Paleontological data are also exploited by commercial fossil dealers and amateur fossil collectors, a situation which then deserves protection by the authorities as a geosite (Saddiqi et al., 2015).

This work, based on lithologic, paleomagnetic, carbon isotope chemostratigraphy and biochronological data, allows us to describe and refine the nature and age of the sedimentological deposits exposed in the Dakhla region, and notably to constrain the dating of its paleontological content (Paleogene faunas). 


\section{Geological setting}

The studied Paleogene succession corresponds to the Samlat Formation (Fm.) of Ratschiller (1967). It is exposed in different areas, notably cliffs along the Atlantic Ocean coast, and have also been recognized in boreholes drillings (Ranke et al., 1982, Davison, 2005) on the continental shelf. There have been few geological studies carried out on these units in the Dakhla area (e.g. Ratschiller 1967; Ortlieb, 1975), which were inappropriately mapped as Mio-Pliocene by Rjimati et al. (2008), and contrary to those devoted to deposits capping the beach cliffs near Dakhla and dated to the Mio-Quaternary period (e.g. Joleaud, 1907; Front Y Sague, 1911; Deperet, 1912; Lecointre 1962, 1966). In the framework of our geological and paleontological program in the early Tertiary of North Africa, since 2013 we have carried out researches in the westernmost part of the Sahara in Morocco, notably on the geological outcrops of the Samlat Formation exposed between Garitas and about $60 \mathrm{~km}$ north of the crossroad at the entrance of the Dakhla peninsula (Fig. 1a, b). Recent paleontological studies in this region have yielded vertebrate fossils, which indicate that some of the deposits are late Eocene in age (Adnet et al., 2010; Zouhri et al., 2014). New sedimentological, geochemical and magnetostratigraphic studies were carried out, in order to refine the age of these Paleogene deposits. Between 2013 and 2015, our field research was devoted to prospecting the outcrops, in search of fossil-bearing levels. The escarpment prospected lies between lat. $22^{\circ} 51^{\prime}$ to the south and lat. $24^{\circ}$ to the north (in some zones the outcrops are covered by modern sand dunes). About $150 \mathrm{~km}$ south of Dakhla, the thickness of the outcrops is reduced and is only a few meters above sea level. It is only from Garitas and beyond to the north, that the escarpment exposes Paleogene sediments, which are notable for their abundant and diverse marine vertebrates. 


\section{Materials and methods}

96

97

In order to reconstruct the past sedimentary environment, outcrops were sought in the Dakhla peninsula and in the surrounding areas. For each outcrop, a number of sections were selected for detailed study along the coastal cliffs. The succession of lithofacies was described from the base to the top of the sequence for each section. The description was essentially based on the lithological characteristic of sediments and the sedimentary structures. This description enabled us to establish correlations between sections based on fossil-bearing levels as previously reported in Adnet et al. (2010).

Field studies included selection of different outcrops with easy access; we measured five stratigraphic sequences, bed by bed, with Jacob Staff. These sections are located about $50 \mathrm{~km}$ south of Dakhla. In addition, a paleomagnetic study was carried out along the Porto Rico section (Fig. 1). A total of 29 cores were drilled in the field from 13 distinct levels with a portable gasoline powered drill, and oriented in situ with a magnetic compass. Most sites drilled correspond to the Unit 2 and the lower part of Unit 3 (see below). The lithology sampled includes sandstones, clays and silts.

Carbon isotope analyses were performed on 43 samples (Table 1) of the Porto Rico (Pto) and El Argoub (Arg) sections. Organic matter of the sediments was isolated, following the procedure described in Yans et al. (2010) and refined by Storme et al. (2012). The bulk organic carbon isotope analyses $\left(\delta^{13} \mathrm{C}_{\text {org }}\right)$ are based on powdered rock samples of about 1 to $10 \mathrm{~g}$, acidified in $25 \% \mathrm{HCl}$ solution for two hours in order to remove carbonate. The numerous carbonate-free samples were treated similarly. Soluble salts were removed by repetitive (1-10) centrifuging (4000 revolutions per minute) with deionized water until a neutral sediment was obtained. Finally, residues were dried at $35^{\circ} \mathrm{C}$ and powdered again. Carbon isotope analysis of organic carbon was performed with an elemental analyzer (CarloErba 1110) connected online to a Thermo Finnigan Delta V Plus masspectrometer at the 
120 University of Erlangen (Germany). Organic ${ }^{13} \mathrm{C} /{ }^{12} \mathrm{C}$ values are normalized to the international 121 VPDB standard (Vienna Pee Dee Belemnite). Each sample was analyzed 1 to 4 times; 122 accuracy and reproducibility of the analyses were checked by replicate analyses of 123 international standards USGS40 and USGS41. The reproducibility of analyses is within $0.2 \%$ $124(1 \sigma)$. The $\mathrm{CaCO}_{3}(\%)$ content of the samples was measured with a Bernard Calcimeter.

\section{Description of lithological units}

128 Western Moroccan Sahara, and defined the Izic Formation (Fm.). Ranging from the latest 129 Miocene up to the Pliocene, the transgressive Aaiun Fm. (Laayoun area) supposed as Late 130 Miocene in age, and the Paleogene Samlat Fm. Primarily based on foraminifera, Ratschiller 131 (1967) subdivided the Samlat Fm. in three Members (Mb.) as follows:

132 - the Morcba Mb., which mainly consists of continental sand deposits with some petrified 133 woods, and that is attributed to the Oligocene.

134 -Early Miocene despite the lack of age evidence.

135 - the thick Guerran Mb., which is primarily a marine siliceous chalk, becoming more clastic 136 farther onshore, and dated to the Eocene on the basis of foraminifera;

137 -the Itgui Mb., which consists principally of marine limestones with flint levels, dated from 138 the Paleocene.

139 The studied deposits of the Dakhla area formally belong to the Samlat Fm., but considering 140 that the lithology of each Ratschiller's Member was defined further north (near Aauinat 141 Tartar, south of Boujdour), we decided here to use lithological units without reference to the 142 Ratschiller's members.

143 In the Dakhla region, the escarpment lies between 10 and $60 \mathrm{~m}$ above the sea level, and forms 144 a west facing cliff, steeping on the upper part but sloping gently at the base. The studied 
145 sections are directly along a steep cliff at the Atlantic coast exposed between the Gulf of 146 Cintra and the N'Tireft village (Fig. 1b). The Paleogene formation is overlain by a 1 to $2 \mathrm{~m}$ 147 thick lumachellic limestone, which is Mio-Pliocene in age (e.g. Joleaud, 1907, Front Y Sague, 148 1911, Deperet, 1912, Lecointre, 1966), and consists of:

149 - alternating marine limestones and marls, rich in organic matter at the base;

150 - alternating sandstones and marls, with intercalations of brown to black siliceous limestones 151 at the middle interval;

152 - sandy white marls at the top.

\section{4.a. Garitas section}

155 sequences into five lithological units (U1-5).

160

161

\section{Unit U1:}

162 This unit represents the lowermost part of the section, as in Adnet et al. (2010), and is composed of a succession of four lithofacies (Fig. 2).

164 1- The first Unit is a rhythmic sequence that consists of gray-beige marl limestone to whitish 165 surface, sometimes siliceous with splintery fracture. This marly limestone, showing sporadic black nodules, alternates with marl gray or blackish rich in organic matter (Fig. 3a-c).The 167 base of this sequence shows a $\sim 10$-cm-thick blackish phosphorite with rich organic matter 168 including numerous coprolites and fish remains (level A1, Fig. 3c). This last level becomes thicker 169 (20-cm thick) and whiter toward the south. 
170 2- Alternating beige marl and siliceous limestone with vertical fissure filled with the same

171 sediments (Neptunian dykes; Fig. 3e-f). The limestone beds show inverse graded bedding

172 (decimetric at the bottom and multi-decimetric at the top). Several coprolite levels (Fig. 4a)

173 are noted, with centimeter to decimeter thick.

174 3- Compact gray limestone bars and beige sandy calcareous marl (Fig. 4b).

175 4- A landmark level composed of black to brown or dark siliceous limestone, rich in 176 coprolites at its base and alternating with beige marls (Fig. 4b).

178 Unit U2:

179 This second unit is composed of two lithofacies.

180 5- Yellowish sandy marl $(\approx 1 \mathrm{~m})$ overlaid by a friable sandy micro-conglomeratic ferruginous

181 level, which is particularly rich in selachians teeth and vertebrates bones (bed B1 of Adnet et

182 al., 2010). This fossil-bearing level B1 (Fig. 4c) has yielded a large number of vertebrae of 183 cetaceans belonging to five different species, with possible rib fragments of sirenians, as well 184 as few remains of crocodiles, turtles, sea snakes and birds (Zouhri et al., 2014).

185 6- Whitish marl level with intercalations of lenticular brown siliceous limestone $(\approx 5 \mathrm{~m})$ (Figs. $1864 \mathrm{~b}$ and $5 \mathrm{a})$.

187

188

Unit U3:

189 This third unit comprises three lithofacies.

190 7- Muddy brown yellow sandstone, sometimes with a secondary gypsum element. This level 191 yields abundant remains of selachians and archaeocetes (basilosaurids) (cf. Bed B2 of Adnet 192 et al., 2010). Zouhri et al., (2014) reported from this level a Basilosaurus sp. and remains of a 193 dugongid (Fig. 6a, b) 
194 8- Fossil-rich beige sandy marl, yielding few dental remains of terrestrial mammals (rodent 195 incisor) and selachians (Level C1).

196 9- Beige sandy marls.

197

198

Unit U4:

199

10- Red Sands $(\approx 0.5 \mathrm{~m})$.

200 Unit U5:

201 11- A consolidated coquina deposit with oysters and gastropods (scallops bed $(\approx 1,5 \mathrm{~m})$ ).

202

203

\section{4.b. Porto Rico section}

204

The section is located about $10 \mathrm{~km}$ east of the Dakhla city, along the seashore of Porto Rico

205

(Fig. 1b). In this area, the available section starts with the bone-bed fossil-bearing level B1 of

206

U2 (Fig. 7), the U1 being under water (or perhaps absent?). This section consists from the

207 bottom to the top of:

208

209

Unit U2:

210 1- At the seashore edge, the geological section begins with an oxidized sandy marl level, rich

211 in vertebrate bones and selachian teeth, corresponding to level B1 of Adnet et al. (2010) (Fig.

212 7a). This very fossiliferous horizon lies on the previous section more than $22 \mathrm{~m}$ above the sea

213 level, and plunges northwardly below the sea level.

214 2- Beige to whitish sandy marls topped by a yellowish and oxidized sandy marl level that is

215 rich in fossils, fossil-bearing level B2 of Adnet et al. (2010) (Fig. 7c). These levels tend to

216 disappear within a few hundred meters to the north of Porto Rico (see Fig. 11 correlation).

217

218 


\section{Unit U3:}

220 3- The middle of the section corresponding to the U3 consists of a thick multicolor sandy marl 221 series, interstratified by sandstone with limestone concretions. A rich level of selachian teeth 222 and bones (Level C1), was identified in the lower part of this interval (Fig. 7b).

223

224

\section{Unit U4:}

225 4- This Unit begins with a very characteristic landmark level consisting of gastropod and 226 oyster coquina (Fig. $7 \mathrm{~b}$ and $7 \mathrm{~d}$ ), white sandy marls in the middle, with another fossil-bearing 227 level C2, including sandstone intercalations.

228

229

Unit U5:

230

5- The section ends with the Mio-Pliocene flagstone consisting of a coquina limestone, which 231 includes oyster shells and gastropods (U5).

\section{Correlation between the sections}

241 The North-South logged sections were correlated based on, at least, five remarkable fossil242 bearing levels (noted $\mathrm{A} 1, \mathrm{~B} 1, \mathrm{~B} 2, \mathrm{C} 1$, and $\mathrm{C} 2$ ). In these measured sections, the 243 aforementioned lithostratigraphic units show lateral variations of facies along the coastline 
244 (Fig. 9). These variations can be explained by the slight northward tilting of these deposits.

245 The five units recognized represent a general regressive trend, which records a transition from 246 an outer ramp into a peritidal zone. The rhythmic bedding might have been caused by 247 fluctuations in the depositional environment.

With the exception of U5, the four units U1-4 are Paleogene in age and thus formally belong to the Samlat Fm. (see before). The correlations with the three members of the Samlat Fm. of Rattschiller (1967) remain hypothetical, and suffer from inconsistent observations. Rattschiller (1967: fig. 176) illustrated a beach cliff around Porto Rico, where he considered that the Aaiun Fm. directly overlies the Lebtaina Fm., a formation underlying the Samlat Fm. However, it seems that what he considered as the Aaiun Fm., rather corresponds to the U3-5 of the Dakhla area, and that the Lebtaina Fm. corresponds to U1-2. Indeed, if it was firstly expected to attribute the U1-2 to the Guerran Mb. and the U3-4 to the Morcba Mb. According Rattschiller (1967), we cannot confirm the lithological divisions of Rattchiller (1967).

\section{Paleomagnetic analysis}

259

Samples were analyzed with the paleomagnetic facilities housed at the iPHEP of the

Université de Poitiers, France. Remanent magnetization was measured with a JR6 magnetometer combined with stepwise thermal or alternating field demagnetization in a magnetically shielded room. To better constrain the magnetic mineralogy, we studied the acquisition of isothermal remanent magnetization (IRM), and then the stepwise thermal demagnetization of three-axis differential IRM following the method of Lowrie (1990). The specimens were subjected to stepwise thermal demagnetization in steps up to $600^{\circ} \mathrm{C}$. The

267 IRM was determined with a pulse electromagnet. Thermal demagnetization was done with a 
269 thermal demagnetization was carried out, in steps of 30 to $40^{\circ} \mathrm{C}$, from $100^{\circ} \mathrm{C}$, until either the 270 magnetization intensity fell below the noise level or the direction became erratic. The

271 majority of specimens were submitted to stepwise alternating field (AF) demagnetization with 272 increments of 5-10 mT, using a Molspin Ltd. high-field shielded demagnetizer. Characteristic 273 magnetization components were isolated by applying the method of Kirschvink (1980) to 274 vector segments with a maximum angular deviation less than $15^{\circ}$.

\section{6.a. Magnetic properties and characteristic directions}

A set of rock magnetic experiments was conducted to characterize and identify the magnetic mineralogy of the main lithologies. We first analyzed the acquisition of IRM (Isothermal Remanent Magnetization) up to $500 \mathrm{mT}$ and its subsequent thermal demagnetization.

281 Following the procedure described by Lowrie (1990), magnetic fields of 1, 0.4 and $0.12 \mathrm{~T}$ 282 were successively applied to each of the three perpendicular directions prior to thermal 283 demagnetization. The IRM acquisition curves (Fig. 11a) show a broad range of coercivities. 284 The initial increase of magnetization up to $100-150 \mathrm{mT}$ indicates the presence of low 285 coercivity minerals. Saturation was achieved between 300 and $500 \mathrm{mT}$, which indicates the 286 presence of intermediate coercivity minerals.

287 Thermal demagnetization shows that the low field $(0.12 \mathrm{~T})$ component is dominant, in figures $28811 \mathrm{~b}, \mathrm{c}$, the first drop appears on the soft and medium components between $300^{\circ} \mathrm{C}$ and $350^{\circ} \mathrm{C}$, 289 indicating the existence of magnetic mineral with soft coercivity, probably corresponding to 290 low-Tititanomagnetite. The second drop is observed at $580^{\circ} \mathrm{C}$ indicating the presence of 291 magnetite. The harder components, less than $25 \%$ of the total IRM, decrease regularly up to 292 temperature of $300-350^{\circ} \mathrm{C}$ and suggest the presence of a Fe-sulphide. 
293 Thermomagnetic curves are routinely used in paleomagnetism to identify remanence carriers.

294 Low-field susceptibility measurements ( $k-T$ curves) were performed using a Bartington 295 susceptibility meter (MS-2) equipped with furnace. Some specimens were heated up to $600^{\circ} \mathrm{C}$ 296 at a heating rate of $10^{\circ} \mathrm{C} \cdot \min -1$, and then were cooled at the same rate (Fig. $\left.11 \mathrm{~d}\right)$. The 297 thermomagnetic behavior of bulk sediment samples shows very low magnetization, in agreement with low intensity of the sample. At about $400^{\circ} \mathrm{C}$, magnetization starts to increase, is maximal at about $500^{\circ} \mathrm{C}$, and then decreases sharply to 0 just before $600^{\circ} \mathrm{C}$. This is due to the presence of pyrite, a paramagnetic mineral that altered towards magnetite near $500^{\circ} \mathrm{C}$ during the experiment (Strechie et al., 2002; Tudryn \& Tucholka, 2004). Cooling curves indicate that magnetite is produced as a result of the thermal breakdown (Fig. 11d). No correct curve was obtained for the majority of samples because of low initial signal of magnetic susceptibility.

305 The natural remanent magnetization displays moderately high values, starting at $8.8 \times 10^{-7} \mathrm{~A} / \mathrm{m}$ 306 in siltstone levels, and reaching up to $\sim 6.3 \times 10^{-4}$, with an average of $1.9 \times 10^{-4} \mathrm{~A} / \mathrm{m}$ (Fig. 10).

307 After some step demagnetization, the magnetization intensity fell below noise level of the magnetometer (Fig. 12a), and the direction became erratic (Fig. 12b). Data resulting from AF and thermal demagnetization were plotted on orthogonal vector plots (Zijderveld, 1967). To determine characteristic magnetic directions, principal components analysis was carried out on all samples. These paleomagnetic directions were then analyzed, using Fisher statistics, to determine site mean declinations, mean inclinations and associated precision parameters. Only tree strata at the upper part of the section gives a coherent result of normal direction $315=24.4, \mathrm{k}=6)$, and differ from the expected direction for this latitude $(\mathrm{I}=27.2, \mathrm{D}=352.2)$ (Fig. $31612 d)$.

(Fig. 12c). The mean directions of ChRM are: declination $=324.4^{\circ}$, inclination $=44.6^{\circ}(\alpha 95$ 
318

319

320

321

322

323

324

325

326

327

328

329

330

331

332

333

334

335

336

337

338

339

340

341

\section{Carbon isotope geochemistry results}

Carbon isotopic values range from $-27.8 \%$ (sample ARG15-2) to -22.1\%o (sample PTO15-11;

Table 1). These data are in good agreement with the expected $\delta^{13} \mathrm{C}$ values on organics at the Eocene-Oligocene interval (see Sarkar et al., 2003). Seven samples have Total Organic Carbon too low $(<0.01 \%)$ to perform reliable isotopic analysis.

In the Porto-Rico section, the $\delta^{13} \mathrm{C}_{\text {org }}$ curve shows the following successive values/trends, from the base to the top (Fig. 13; Table 1):

1. relatively negative $\delta^{13} \mathrm{C}_{\text {org }}$ value (-27.6\%) in the $\mathrm{B} 1$ fossil-bearing level, at the base of the section (lowermost part of unit U2);

2. relatively stable $\delta^{13} \mathrm{C}_{\text {org }}$ values (from -25.1 to $-24.3 \%$ ) in the U2 (including the fossilbearing B2 level);

3. relatively negative $\delta^{13} \mathrm{C}_{\text {org }}$ value, around $-25.7 \%$ in the lower part of U3 (including the C1 fossil-bearing level);

4. relatively stable $\delta^{13} \mathrm{C}_{\text {org }}$ values (from -25.2 to $-24.6 \%$ ) in the upper part of $\mathrm{U} 3$;

5. prominent and rapid positive shift of $\delta^{13} \mathrm{C}_{\text {org }}$ values, from $-26.2 \%$ to $-22.1 \%$ in the uppermost part of $\mathrm{U} 3$ and $\mathrm{U} 4$;

6. negative shift of $\delta^{13} \mathrm{C}_{\mathrm{org}}$ values, from $-22.1 \%$ to $-25.4 \%$ in the lower part of U5 (including the $\mathrm{C} 2$ fossil-bearing level);

7. positive shift of $\delta^{13} \mathrm{C}_{\text {org }}$ values, from $-25.4 \%$ to $-23.7 \%$ in the upper part of U5;

8. negative shift of $\delta^{13} \mathrm{C}_{\text {org }}$ values, from $-23.7 \%$ to $-25.2 \%$ in the uppermost part of U5.

In the $\mathrm{E}$ l Argoub section, the $\delta^{13} \mathrm{C}_{\text {org }}$ curve shows the following successive values/trends, from the base to the top (Fig. 13; Table 1):

1. prominent and rapid positive shift of $\delta^{13} \mathrm{C}_{\text {org }}$ values, from $-27.8 \%$ o to $-23.4 \%$ in the uppermost part of $\mathrm{U} 3$ and $\mathrm{U} 4$; 
2. negative shift of $\delta^{13} \mathrm{C}_{\text {org }}$ values, from $-23.4 \%$ to $-25.7 \%$ in the lower part of U5 (including the $\mathrm{C} 2$ fossil-bearing level);

3. positive shift of $\delta^{13} \mathrm{C}_{\text {org }}$ values, from $-25.7 \%$ to $-23.0 \%$ in the upper part of U5;

4. negative shift of $\delta^{13} \mathrm{C}_{\text {org }}$ values, from $-23.0 \%$ to $-25.5 \%$ in the uppermost part of U5.

The $\mathrm{CaCO}_{3}$ contents range from 0.0 to $76.9 \%$ in the Porto-Rico section and from 0.0 to $45.3 \%$ in the El Argoub section.

\section{8- DISCUSSION}

The fossil content of the Dakhla deposits is rich and varied, mixing primarily selachians and marine mammals (cetaceans and sirenians). Ratschiller (1967) first mentioned the occurrence of fish teeth in the Eocene Guerran Mb. of the Samlat Fm. In the Dakhla area, a rich vertebrate fauna was discovered by Adnet et al., (2010) in two levels: B1 and B2. The Eocene age proposed by Ratschiller (1967) and later by Adnet et al. (2010) was based on paleontological evidence. Indeed, the majority of selachian taxa (such as Xiphodolamia serrata, Misrichthys stromeri and Cretolamna twiggsensis) recovered in B1 and B2 are known elsewhere in deposits dating from the Bartonian and Priabonian (e.g. Qasr El Sagha Fm. [Egypt], Qa'Faydat and the Wadi Esh-Shallala Fm. [Jordan], or the Drazinda Shale Mb. of the Kirthar Fm. [Pakistan] (Adnet et al., 2010). Later, Zouhri et al. (2014) described five archaeocete cetacean species from the level B1, and dugongid sirenians in the level B2; faunal correlations with the late Eocene of Egypt indicate a Priabonian age for the B1 and B2 fossil assemblages.

Since 2013, our fieldwork allowed the discovery of new fossil-bearing levels in the stratigraphic sequence (A1, C1, and C2). The lowermost part of the Garitas section (U1; Figs. 2 and 3) has yielded a fossil-bearing level including a diverse assemblage of fish (e.g. “Carcharias" koerti, Physogaleus aff. tertius, Coupatezia spp. Merabatis sp., Burhnamia sp., 
368 Cyladrincanthus sp.). In the Porto Rico section (Fig. 7), two stratigraphically distinct levels

369 have yielded fossil vertebrates. The level $\mathrm{C} 1$, located at the base of U3 has yielded an 370 assemblage of selachians (e.g. Carcharhinus spp. Carcharias sp., Pristis cf. lathami, 371 Pastinachus sp., Aetobatis cf. irregularis). Above in the section, the base of U4 has yielded a 372 fossil assemblage (C2) of marine and estuarine invertebrates (lamellibranches) and vertebrates 373 (including fishes, turtles, crocodiles, and selachians resembling to $\mathrm{C} 1$ ), together with 374 terrestrial mammals (including rodents, primates, hyracoids, an elephant shrew, and 375 creodonts). A strictly similar fossil assemblage was found in the El Argoub section, in 376 equivalent deposits (i.e. at the base of U4).

377 The mammal fossils of C2 (Porto Rico and El Argoub) consist of isolated teeth, but also 378 partial jaws and bone fragments. Among the mammals, afrotherians are illustrated by a 379 herodotiine macroscelid (Herodotius aff. pattersoni) and several "saghatheriid" hyracoids, 380 among which is a species of Saghatherium. Primates include an oligopithecid anthropoid 381 (Catopithecus aff. browni) and an indeterminate afrotarsiid. Rodents are much more abundant 382 and represented by members of two phylogenetically distinct groups: Hystricognathi and 383 Anomaluroidea. Several tens of isolated teeth of anomaluroids indicate the presence of two 384 distinct families, Anomaluridae and Nonanomaluridae, and possibly the ancestral family 385 Zegdoumyidae, represented by five new species (Argouburus minutus, Paranomalurus 386 riodeoroensis, Dakhlamys ultimus, Oromys zenkerellinopsis, and Nonanomalurus parvus; see 387 Marivaux et al. 2017). Regarding hystricognaths (Marivaux et al., in press), distinct taxa are 388 recognized, primarily including several "phiomyid"-like representatives (Birkamys aff. korai, 389 Mubhammys sp. nov., ?Phiocricetomys sp., Neophiomys sp. nov., and a new genus and 390 species) and gaudeamurids (Gaudeamus cf. hylaeus and G.cf. aslius). Most of these Dakhla 391 C2 mammals (except anomaluroids; Marivaux et al., 2017), or at least their close relatives, 392 have been originally described from well-known Egyptian localities of the Jebel Qatrani 
393 Formation (Fayum Depression), dating from the latest Eocene (L-41; Hyracoidea: Rasmussen

394 \& Gutiérrez 2010; Macroscelididae: Simons et al. 1991; Primates: Simons 1995; Simons \& 395 Rasmussen 1996; Seiffert 2012; Rodentia: Sallam et al. 2011; Sallam \& Seiffert, 2016) or the 396 early Oligocene (Hyracoidea: Rasmussen \& Gutiérrez 2010; Rodentia: Wood, 1968). This 397 faunal similarity thus indicates a latest Eocene-early Oligocene time frame for the 398 fossiliferous concentration of the level C2 of the Pto-Arg sector.

399 Here we performed new chemostratigraphic investigation using carbon isotopes from 400 dispersed organic matter $\left(\delta^{13} \mathrm{C}_{\mathrm{org}}\right)$ on the Porto Rico and $\mathrm{El}$ Argoub sections, in order to refine 401 the stratigraphic framework of the Samlat Fm. in the Dakhla area. As mentioned above, Adnet 402 et al. (2010) suggested a Bartonian to Priabonian age for the fossil-bearing levels B1 and B2 403 on the basis of the selachian fauna. Later, Zouhri et al. (2014) refined the age of the level B1 404 and proposed early-middle Priabonian on the basis of the cetacean fauna. These authors also 405 suggested a Priabonian age for the level B2 on the basis of the sirenian fauna. It implies that 406 the lower part of the studied sections, containing the levels B1 and B2, is (early-middle) 407 Priabonian in age, thereby suggesting that the upper part of the section is Priabonian or 408 younger.

409 The Eocene-Oligocene boundary (EOB; 34Ma) is the largest global cooling of the 410 Cenozoic Era and led the Earth's climatic system to change from a greenhouse to an icehouse 411 mode, well documented in marine setting (e.g. Bohaty et al., 2012) and, to a lesser extent in 412 continental setting (e.g. Tramoy et al., 2016). The cooling interval, initiated in the late 413 Eocene, comprise several isotopic events, which have been coded by Miller et al. (1991). The 414 oldest of the events, coded Oi-1 or Eocene-Oligocene (climate) transition or EOT, is 415 associated with major $\delta^{18} \mathrm{O}$ and $\delta^{13} \mathrm{C}$ positive shifts, starting in the late Eocene and ending in 416 the early Oligocene (e.g. Coxall et al., 2005; Katz et al., 2008; Lear et al., 2008). Using a 417 high-resolution carbon isotope study of the ODP site 1218, Erhardt et al. (2013) showed that 
418 the carbon and oxygen positive shifts of the Oi-1 event are followed by two positive $\delta^{13} \mathrm{C}$ and

$419 \delta^{18} \mathrm{O}$ excursions called Oi-1a and Oi-1b, early Oligocene in age. This isotopic pattern was also 420 observed by Zhifei et al. (2004) in ODP Leg 208 Site 1262, 1265 and 522.

421 In the Porto Rico (Pto) and El Argoub (Arg) sections (this study; Fig.13), the Oi-1 event 422 initiates in the uppermost part of the U3 lithological unit $(\sim 2$ meters below the $\mathrm{C} 2$ level $)$ and 423 ends below the $\mathrm{C} 2$ level. This isotopic event is followed by one positive excursion (positive 424 shift followed by a negative shift), interpreted here as Oi-1a. In summary, the C2 level is 425 clearly above the Oi-1, and as such it is probably earliest Oligocene in age.

426 Lower, the B1 and B2 fossil-bearing levels are dated as Priabonian by the selachian, cetacean 427 and sirenian faunas (see above). The $\mathrm{C} 1$ level is located in a negative $\delta^{13} \mathrm{C}$ excursion (Fig.13). 428 This latter should correspond to the carbon isotope excursion observed in the Priabonian 429 (NP19-20 Zones). The B1 level shows negative $\delta^{13} \mathrm{C}$ value, most probably corresponding to 430 the negative $\delta^{13} \mathrm{C}$ values in the early Priabonian NP18 Zone (Fig.13).

431 The paleomagnetic analysis show that the only normal polarity is represented by tree strata 432 situated $2 \mathrm{~m}$ above the $\mathrm{C} 1$ fossiliferous level. Although the rock magnetic properties suggest 433 that the NRM may be of primary origin, we evaluate other criteria to infer the origin of the 434 observed characteristic remanence. In situ site mean directions differ significantly from the 435 direction of the axial geocentric dipole at the latitude of the site (Fig. 12D) and, therefore, 436 exclude a recent magnetic overprint. Correlation of the Porto Rico section with the 437 geomagnetic polarity time scale (GPTS) of Gradstein et al. (2012) was performed by 438 considering the earliest Oligocene age discussed above for C2 level and Priabonian age for B2 439 and $\mathrm{C} 1$. Taking into account the biochronological age, the normal polarity might then be 440 correlated to ChronC16n. 
442 Our new chemostratigraphic and paleomagnetic data suggest that the C2 fossil-bearing level 443 of Dakhla is clearly located above the Oi-1 event and below the Oi-1a event. The Oi-1 event, 444 bringing the major cooling, is recognized by many authors to occur a few 100 kyr later than 445 the GSSP (Global Boundary Stratotype Section and Point) of the Rupelian (Eocene-Oligocene 446 boundary; Vandenberghe et al., 2012). The GSSP of the Eocene-Oligocene boundary is 447 defined in the Massignano section (Italy), and the key marker of the GSSP is the extinction of 448 the hantkeninid planktonic foraminifera, which lies within nannofossil Zone NP21 (Premoli449 Silva \& Jenkins, 1993).Katz et al. (2008) showed that 1) the Oi-1 event is located around the 450 transition of Chron C13r and C13n (33.545 Myr), and 2) the Oi-1a event is located around the 451 transition of Chron C13n and C12r. It suggests that the C2 level, located just above the Oi-1 452 event and below the Oi-1a event, is a few 100 kyr above the Eocene-Oligocene boundary, 453 within the nannofossil Zone NP21and into the magnetic polarity Chron 13n.Interestingly, as 454 mentioned above, Gingerich (1993) suggested that the L-41 level (lower part of the Jbel 455 Qatrani Fm.) is located in the early Oligocene. Underwood et al. (2013) places the base of the 456 Jebel Qatrani Formation close to the base of Chron C13n. On the other hand, Seiffert (2006) 457 concluded that the L-41 of Fayum bed falls within a zone of reverse polarity and correlated 458 with Chron 13r, late Eocene, i.e older than the C2 level of Dakhla. The new rodent 459 assemblage from the earliest Oligocene of Dakhla (Sahara, Morocco), represents therefore the 460 first Oligocene record of rodents from northwestern Saharan Africa, especially from the 461 Atlantic margin of that landmass. The carbon isotope chemostratigraphy confirms that the 462 lower part of the studied sections, containing the levels B1 and B2, is early-middle Priabonian 463 in age.

464 Our knowledge of the mammal faunas documenting the early Oligocene of Afro-Arabia has 465 so far derived from contemporary localities found in northern Egypt (Fayum Depression), 466 Libya (Zallah Oasis) and Oman (Dhofar Province) (Fejfar, 1987; Sallam et al., 2011, 2016, 
467 Coster et al., 2010, 2012, Sallam \& Seiffert, 2016). This new earliest Oligocene mammal 468 fauna from the northern Atlantic margin of Africa is of great interest because it documents for 469 the first time the diversity of micomammals, especially rodents. Biochronology and C isotope 470 chemostratigraphy provide an Oligocene age constraint of C2 fossiliferous level, and thus 471 increase our understanding of the timing of mammal evolution and environmental changes in

472 North Africa at that time.

473 Acknowledgments

474 We would like to thank Abdallah Tarmidi and Mbarek Fouadasi for their help during the field 475 work. Financial supports during the field work were provided by the French ANR EVAH 476 (ANR-09-BLAN-0238) and ANR-ERC PALASIAFRICA (ANR-08-JCJC-0017) Programs, 477 the ISE-M UMR 5554CNRS/UM/IRD/EPHE, CNRS-CoopIntEER171834, and iPHEP UMR 478 CNRS 7262. C.N. and J.Y thank the project BR/121/A3/PALEURAFRICA of the Belgian Science 479 Policy Office. 
REFERENCES CITED

482

483

484

485

486

487

488

489

490

491

492

493

494

495

496

497

498

499

500

501

502

503

504

505

ADNET, S., CAPPETTA, H. \& TABUCE, R. 2010. A Middle-Late Eocene vertebrate fauna (marine fish and mammals) from southwestern Morocco; preliminary report: age and palaeobiogeographical implications. Geological Magazine 147, 860-870.

BENAMMI, M., ELKATI, I., ADNET, S., MARIVAUX, L., TABUCE, R., SURAULT, J., BAIDDER, L., SADDIQI, O. \& BENAMMI, M. 2014. Corrélation de coupes lithostratigraphiques le long des falaises côtières dans la region d'El Argoub (Dakhla, Maroc): Second North African Vertebrate Palaeontology Congress-NAVEP2, Ouarzazate, Morocco, 1-8 September, Abstracts, p.37.

BENAMMI, M., ELKATI, I., ADNET, S., MARIVAUX, L., TABUCE, R., SURAULT, J., BAIDDER, L., SADDIQI, O. \& BENAMMI, M., 2014. Preliminary paleomagnetic data in the Dakhla, Southwestern Moroccan Sahara: Second North African Vertebrate Palaeontology Congress-NAVEP2, Ouarzazate, Morocco, 1-8 September, Abstracts, p.40.

BOHATY, S.M., ZACHOS, J.C. \& DELANEY, M.L. 2012. Foraminiferal Mg/Ca evidence for Southern Ocean cooling across the Eocene/Oligocene transition. Earth and Planetary Science Letters 317-318, 251-261.

COSTER, P., BENAMMi, M., LAZZARI, V., BILlet, G., MARTIN, T., SALEM, M., ABOLHASSAN BILAL, A., CHAIMANEE, Y., SCHUSTER, M., VALENTIN, X., BRUNET, M. \& JAEGER, J.-J., 2010. Gaudeamuslavocati sp. nov. (Rodentia, Hystricognathi) from the lower Oligocene of Zallah, Libya: First African Caviomorph?. Naturwissenschaften 97, 697-70.

COSTER, P., BENAMmi, M., SALEM, M., BILAL AWAD, A., CHAIMANEE, Y., VALENTIN, X., BRUNET M. \& JAEGER, J.J., 2012. New hystricognathous rodent from the Early Oligocene of central Libya, (Zallah Oasis, Sahara Desert): systematic, 
506

507

508

509

510

511

512

513

514

515

516

517

518

519

520

521

522

523

524

525

526

527

528

529

phylogenetic, and biochronologic implications. Annals of Carnegie Museum 80, 239259.

COXALL, H.K., WILSON, P.A., PÄLIKE, H., LEAR, C.H. \& BACKMAN, J. 2005. Rapid stepwise onset of Antarctic glaciation and deeper calcite compensation in the Pacific Ocean. Nature 433, 53-57.

CRAMER, B.S., TOGGWEILER, J.R., WRIGHT, J.D., KATZ, M.E. \& MILLER, K.G., 2009. Ocean overturning since the Late Cretaceous: inferences from a new benthic foraminiferal isotope compilation. Paleoceanography, published online 23 December 2009.doi:10.1029/2008PA001683.

DAVISON, I. 2005. Central Atlantic margin basins of North West Africa: geology and hydrocarbon potential (Morocco to Guinea). Journal of African Earth Sciences 43 (1-3), $254-274$.

DAVISON, I. \& DAILLY, P. 2010. Salt tectonics in the Cap Boujdour Area, Aaiun Basin, NW Africa. Marine and Petroleum Geology 27, 435-441.

DEPERET, C. 1912. Sur l'âge des couches du Rio de Oro. Comptes Rendus de l'Académie des Sciences 13, 123-124

ERHARDT, A.M, PÄLIKE H. \& PAYTAN. A. 2013. High-resolution record of export production in the eastern equatorial Pacific across the Eocene-Oligocene transition and relationships to global climatic records. Paleoceanography, published online 25 March 2013.doi:10.1029/2012PA002347.

FEJFAR, O. 1987. Oligocene rodents from Zallah Oasis, Libya. Münchner Geowissenschaftliche Abhandlungen A10, 265-268.

FRONT Y SAGUE, N. 1911. Les formations géologiques du Rio de Oro, Sahara espagnol. Bulletin de la Société Géologique de France 4, 212-217 
530 JOLEAUD, L. 1907. Note sur quelques dents de Poissons fossiles du Rio de Oro (Sahara $531 \quad$ occidental). Bulletin de la Société Géologique de France 7, 514.

532 GINGERICH, P.H. 1993. Oligocene age of the Gebel Qatrani Formation, Fayum, Egypt. $533 \quad$ Journal of Human Evolution 24, p. 207-218.

534

GRADSTEIN, F.M., OGG, J.G., SCHMITZ, M.D., \& OGG, G.M., (eds.), 2012. The geologic 535

time scale 2012. Amsterdam, Netherlands, Elsevier, 1144 p.

KATZ, M.E., MILLER, K.G., WRIGHT, J.D., WADE, B.S., BROWNING, J.V., CRAMER, B.S. \& ROSENTHAL, Y. 2008. Stepwise transition from the Eocene greenhouse to the Oligocene icehouse. Nature Geosciences 1, 329-334.

KIRSCHVINK, J.L. 1980. The least-square line and plane and analysis of palaeomagnetic data. Geophysical Journal of the Royal Astronomical Society 62, 699-718.

KLINGELHOEFER, F., LABAILS, C., COSQUER, E., ROUZO, S., GÉLI, L., ASLANIAN, D., OLIVET, J.-L. , SAHABI, M., NOUZÉ, H. \& UNTERNEHR, P. 2009. Crustal structure of the SW-Moroccan margin from wide-angle and reflection seismic data (the Dakhla experiment) Part A: Wide-angle seismic models. Tectonophysics 468, p. 63-82.

KOLONIC, S., SINNINGHEDAMSTÉ, J.S., BÖTTCHER, M.E., KUYPERS, M.M.M., KUHNT, W., BECKMANN, B., SCHEEDER, G. \& WAGNER, T. 2002. Geochemical characterization of Cenomanian/Turonian black shales from the Tarfaya Basin (SW Morocco). Journal of Petroleum Geology 25, 325-350.

LEAR, C.H., BAILEY, T.R., PEARSON, P.N., COXALL, H.K. \& ROSENTHAL, Y. 2008. Cooling and ice growth across the Eocene-Oligocene transition. Geology 36, 251-254.

LECOINTRE, G. 1962. Sur la géologie de la presqu'ile de villa Cisneron, Rio de Oro. Comptes Rendus de l'Académie des Sciences 254, 1121-1122.

LECOINTRE, G. 1966. Néogène et Quaternaire du Rio de Oro (Maroc Espagnol). Comptes Rendus de l'Académie des Sciences 10, 404-405. 
555 LIU, Z., TUO, S., ZHAO, Q., CHENG, X. \& HUANG, W. 2004. Deep-water earliest 556 Oligocene Glacial Maximum (EOGM) in South Atlantic. Chinese Science Bulletin 49, $557 \quad 2190-2197$.

558 LOWRIE, W. 1990. Identification of ferrimagnetic minerals in rock by coercivity and 559 unblocking temperature properties. Geophysical Research Letters, 17, 159-162.

560

561

562

563

564

565

566

567

568

569

570

571

572

573

574

575

576

577

578

579

MARIVAUX, L., ADNET, S., BENAMMI, M., TABUCE, R., \& BENAMMI, M., 2017. Anomaluroid rodents from the earliest Oligocene of Dakhla, Morocco, reveal the longlived and morphologically conservative pattern of the Anomaluridae and Nonanomaluridae during the Tertiary in Africa. Journal of Systematic Palaeontology, published online 10 August 2016, doi:10.1080/14772019.2016.1206977.

MARIVAUX, L., ADNET, S., BENAMMI, M., TABUCE, R., YANS, Y., \& BENAMMI, M., in press. Earliest Oligocene hystricognathous rodents from the Atlantic margin of Northwestern Saharan Africa (Dakhla, Morocco): systematic, paleobiogeographical and paleoenvironmental implications. Journal of Vertebrate Paleontology.

MILLER, K.G., WRIGHT, J.D. \& FAIRBANKS, R.G. 1991. Unlocking the ice house: Oligocene-Miocene oxygen isotopes, eustasy and margin erosion. Journal of Geophysical Research 96, 6829-6848.

ORTLIEB, L. 1975. Recherches sur les formations plio-quaternaire du littoral Ouest Saharien (2830’-2040’). PhD thesis, Pierre et Marie-Curie University, Paris VI - Trav. et Doc. ORSTOM, 48, 267p.

PREMOLI-SILVA, I. \& JENKINS, D.G. 1993. Decision on the Eocene-Oligocene boundary stratotype. Episodes 16, 379-382.

RANKE, U., VON RAAD, U. \& WISSMANN, G. 1982. Stratigraphy, facies, and tectonic development of on- and offshore Aaiun-Tarfaya Basin a review. In Geology of the North West African Continental Margin (ed U. Von Raad), pp 86-104. Springer-Verlag. 
580 RASMUSSEN, D.T. \& GUTIÉRREZ, M. 2010. Hyracoidea. In the Cenozoic Mammals of 581 Africa (eds L.Werdlin \& W.J. Sanders), pp.123-146. University of California Press, $582 \quad$ Berkeley.

583 RATSCHILLER, L.K. 1967. Sahara, correlazioni geologico-litostratigrapfiche fra Sahara 584 Centrale ed Occidentale. Mem. Mus. Tridentino Sc. Nat., 16, 55-190.

585

586

587

588

589

590

591

592

593

594

595

596

597

598

599

600

601

602

603

604

RJIMATI, E., ZEMMOURI, A., BENLAKHDIM, A., AMZAEHOU, M., ESSALMANI, B., MUSTAPHI, H., HAIMOUK, M. \& HAMIDI, F. 2008. Carte Géologique du Maroc. Ad-Dakhla, 1/100 000. Notes et Mémoires Service Géologique du Maroc, 487

SADDIQI, O., RJIMATI, E., MICHARD, A., SOULAIMANI, A. \& OUANAIMI, H. 2015. Recommended Geoheritage Trails in Southern Morocco: A 3 Ga Record Between the Sahara Desert and the Atlantic Ocean. In From Geoheritage to Geoparks, Case Studies from Africa and Beyond (eds E. Errami, B. Margaret \& S. Vic), pp. 91-108. Springer.

SACHSE, V.F., LITTKE, R., HEIM, S., KLUTH, O., SCHOBER, J., BOUTIB, L., JABOUR, H., PERSSEN, F. \& SINDERN, S., 2011. Petroleum source rocks of the Tarfaya Basin and adjacent areas, Morocco. Organic Geochemistry 42, 209-227.

SACHSE, V.F., HEIM, S., JABOUR, H., KLUTH, O., SCHÜMANN, T., AQUIT, M. \& LITTKE, R. 2014. Organic geochemical characterization of Santonian to Early Campanian organic matter-rich marls (Sondage No. 1 cores) as related to OAE3 from the Tarfaya Basin, Morocco. Marine and Petroleum Geology 56, 290-304.

SALLAM, H.M., SEIFFERT, E.R. \& SIMONS, E.L. 2011. Craniodental morphology and systematics of a new family of hystricognathous rodents (Gaudeamuridae) from the Late Eocene and Early Oligocene of Egypt. PLOS ONE 6, e16525eol.

SALLAM, H.M. \&SEIFFERT, E.R. 2016. New phiomorph rodents from the latest Eocene of Egypt, and the impact of Bayesian "clock" based phylogenetic methods on estimates of basal hystricognath relationships and biochronology. PeerJ 4, e1717. 
605 SARKAR, A., SARANGIB, S., EBIHARAC, M., BHATTACHARYAD, S.K. \& RAYE, 606 A.K. 2003.Carbonate geochemistry across the Eocene/Oligocene boundary of Kutch, 607 western India: implications to oceanic O2-poor condition and foraminiferal extinction: $608 \quad$ Chemical Geology 201, 281-293.

609 SEIFFERT, E.R. 2006. Revised age estimates for the later Paleogene mammal faunas of 610 Egypt and Oman. Proceedings of the National Academy of Sciences of the USA 103, $611 \quad 5000-5005$.

612 SEIFFERT, E.R. 2012. Early primate evolution in Afro-Arabia. Evolutionary Anthropology $613 \quad 21,239-253$.

614 SIMONS, E.L. \& RASMUSSEN, D.T. 1996. Skull of Catopithecus browni, an early Tertiary 615 catarrhine. American Journal of Physical Anthropology 100, 261-292.

616 SIMONS, E.L., HOLROYD, P.A \& BOWN, T.M. 1991. Early Tertiary elephant shrews from 617 Egypt and the origin of the Macroscelidea. Proceedings of the National Academy of $618 \quad$ Sciences of the USA 88, 9734-9737.

619 STORME, J.-Y., DEVLEESCHOUWER, X., SCHNYDER, J., CAMBIER, G., BACETA, 620 J.I., PUJALTE, V., IACUMIN, P. \& YANS, J. 2012. Paleocene/Eocene boundary 621 section at Zumaia (Basque-Catabric Basin) revisited: new insights from high resolution 622 magnetic susceptibility and carbon isotope chemostratigraphy on organic matter $623 \quad\left(\delta^{13} \mathrm{C}_{\mathrm{org}}\right)$. Terra Nova $\mathbf{2 4}, 310-317$.

624 STRECHIE, C., ANDRE, F., JELINOWSKA, A., TUCHOLKA, P., GUICHARD, F., 625 LERICOLAIS, G. \& PANIN, N. 2002. Magnetic minerals as indicators of major 626 environmental change in Holocene Black Sea sediments: preliminary results. Physics $627 \quad$ Chemistry Earth 27, 1363-1370.

628 TRAMOY, R., SALPIN, M., SCHNYDER, J., PERSON, A., SEBILO, M., YANS, J., 629 VAURY, V., FOZZANI, J. \& BAUER, H. 2016. Stepwise paleoclimate change across 
TUDRYN, A. \& TUCHOLKA, P. 2004. Magnetic monitoring of thermal alteration for natural pyrite and greigite. Acta Geophysica Polonica 52, 509-520.

UNDERWOOD, C.J., KING, C. \& STEURBAUT, E. 2013. Eocene initiation of Nile drainage due to East African uplift. Palaeogeography, Palaeoclimatology, Palaeoecology 392, 138-145.

VANDENBERGHE, N., HILGEN, F.J. \& SPEIJER, R. 2012. The Paleogene Period. In The Geological Time Scale. (eds F.M. Gradstein, J.G. Ogg, M.D. Schmitz, G.M. Ogg). 2012. Elsevier Science Ltd, Oxford 2, 855-921.

YANS, J., GERARDS, T., GERRIENNE, P., SPAGNA, P., DEJAX, J., SCHNYDER, J., STORME, J.-Y. \& KEPPENS, E. 2010. Carbon-isotope of fossil wood and dispersed organic matter from the terrestrial Wealden facies of Hautrage (Mons basin, Belgium). Palaeogeography, Palaeoclimatology, Palaeoecology 291, 85-105.

WOOD, A.E. 1968. Part II: The African Oligocene Rodentia; in Early Cenozoic Mammalian Faunas Fayum Province, Egypt (ed J.E. Remington). pp. 23-105. Peabody Museum of Natural History Yale University, New Haven, Connecticut.

ZHIFEI, L., SHOUTING, T., QUANHONG Z., XINRONG, C. \& WEI, H. 2004. Deep-water Earliest Oligocene Glacial Maximum (EOGM) in South Atlantic. Chinese Science Bulletin 49, 2190-2197.

ZIJDERVELD, J. D. A. 1967. AC demagnetization rocks-Analyses of results. In Methods in paleomagnetism (eds D. W. Collinson, K.M. Creer \& S.K. Runcorn), p. 254-286. Amsterdam, Netherlands, Elsevier Scientific.

ZOUHRI, S., GINGERICH, P.D., EL BOUDALI, N., SEBTI, S., NOUBHANI, A., RAHALI, M. \& MESLOUH, S. 2014. New marine mammal faunas (Cetacea and Sirenia) and sea 
655 level change in the Samlat Formation, upper Eocene, near Ad-Dakhla in southwestern 656 Morocco. Comptes Rendus Palevol 13, 599-610.

657

658 


\section{Figures captions}

660 Figure 1: Geographic location of the Dakhla peninsula, south of Morocco. (a), map of 661 Morocco with principal towns; (b), location of the geological sections studied (stars). 1: 662 Garitas, 2: Porto Rico, 3: El Argoub. The black circles denote the outcrops of interest along 663 the Atlantic Ocean coast.

664 Figure 2: Stratigraphic section of the Garitas sedimentological sequence. U1-U5 refers to the 665 unit and the number on the right of the column represents the lithofacies.

666 Figure 3: Field photographs showing: (a) a general view of the lower part of the Garitas 667 section, horizontal heterolithic stratification; (b) a detail of A, showing blackish (A1) rich in 668 organic matter levels; (c) a phosphorite rich organic matter with shark teeth (fossil-bearing 669 level A1); (e) the beige marl and siliceous limestone with Neptunian dykes in (f).

670 Figure 4: Field photographs showing: (a) an example of coprolite level; (b) a succession of 671 gray limestone bar and beige sandy calcareous marl (lithofacies 3 in figure 2), black to brown 672 or dark siliceous limestone with coprolites at its base (lithofacies 4), yellowish sandy marl 673 rich in vertebrate fossil, fossil-bearing level B1 (lithofacies 5); (c) a whitish marl with 674 lenticular brown siliceous limestone (lithofacies 6).

675 Figure 5: Garitas section. (a) lithofacies 6 forms the prominent ledge; (b) overlaying muddy 676 brown yellow sandstone corresponding to fossil-bearing level B2 (lithofacies 7).

677 Figure 6: Field photographs showing the top of the Garitas section with lithofacies 9, 10 and $678 \quad 11$.

679 Figure 7: Porto Rico section. (a) general view of the lower part of the section with the fossil680 bearing levels B1 and B2; (b) exposure of the Unit U3 corresponding to the lithofacies 3, 681 which consists of a thick multicolor sandy marl series interstratified by sandstone with 682 limestone concretions (we can see the position of fossil-bearing levels C1 and C2); (c) 
683 photograph showing the abundant selachian teeth of the B2 level; (d) landmark level of 684 gastropods and oysters coquina.

685 Figure 8: field photographs and measured section of North Porto Rico and El Argoub areas. 686 (a) section located $2 \mathrm{~km}$ north of El Argoub village, (b, c) sections is about $6 \mathrm{~km}$ north of 687 Portorico. See the landmark level consisting of gastropod and oyster coquina at the lower part 688 of U4.

689 Figure 9: Outline correlation between cross sections from Garitas to El Argoub.

690 Figure 10: Porto Rico section and position of paleomagnetic sampling and the NRM 691 intensities plotted against lithostratigraphic position (right curve). Note the position of the 692 fossil-bearing B1, B2, C1 and C2.

693 Figure 11: Paleomagnetic analysis: (a) acquisition of isothermal remanent magnetization 694 (IRM) (normalized values) curves of same samples, with most of the magnetization acquired 695 below $200 \mathrm{mT}$ and saturation achieved at $300 \mathrm{mT}$; (b, c) stepwise thermal demagnetization of 696 the IRM components; (d) thermomagnetic curve of sample, where magnetic iron sulphides 697 where suspected to be present in the samples.

698 Figure 12: Demagnetization plots of the samples. The solid (open) symbols represent 699 horizontal (vertical) projections, respectively. (a) at $10 \mathrm{mT}$, the magnetization intensity fall 700 below the noise level of the magnetometer; (b) example of samples with erratic direction; (c) 701 example of samples with normal polarity from the site situated $2 \mathrm{~m}$ above the $\mathrm{C} 1$ fossil702 bearing level; (d) equal area projection and Fisher statistics of the reliable characteristic 703 remanent magnetization (ChRM) direction. The 95\% confidence ellipse for the normal (solid 704 star) mean directions is indicated (inclination $=44.6^{\circ}$, declination $=324.4^{\circ}$ ). Gray star is the 705 geocentric axial dipole of the Porto Rico latitude. 
706 Figure 13: Carbon isotope values (\%o VPDB) of the Porto Rico and El Argoub sections, 707 compared to $\delta^{13}$ Ccurves around the Eocene-Oligocene transition in ODP Site 1218 (Erhardt et 708 al., 2013) and reference $\delta^{13} \mathrm{C}$ composite curve (Cramer et al., 2009 modified by 709 Vandenberghe et al., 2012). EOT=Eocene-Oligocene Transition; U1 to U5 refer to the 710 lithological units defined in the text. B1, B2, C1 and C2 are fossil-bearing levels.

711 Table 1: Sample labels, $\mathrm{CaCO}_{3}$ content $(\%)$ and $\delta^{13} \mathrm{C}_{\mathrm{org}}$ values (\%o, VPDB); N.A.= not 712 analyzed. 
Geographic location of the Dakhla peninsula, south of Morocco. (a), map of Morocco with principal towns; (b), location of the geological sections studied (stars). 1: Garitas, 2: Porto Rico, 3: El Argoub. The black circles denote the outcrops of interest along the Atlantic Ocean coast.

$$
169 \times 83 \mathrm{~mm}(300 \times 300 \mathrm{DPI})
$$




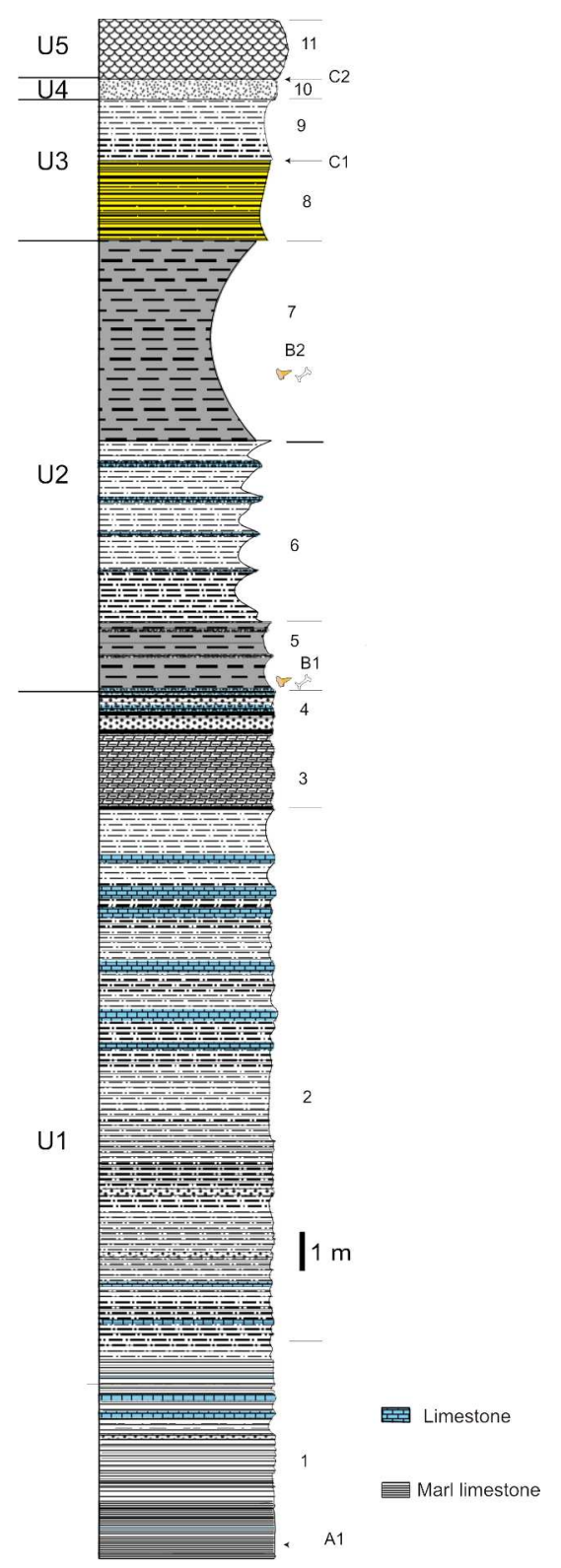

Stratigraphic section of the Garitas sedimentological sequence. U1-U5 refers to the unit and the number on the right of the column represents the lithofacies.

$79 \times 234 \mathrm{~mm}(300 \times 300 \mathrm{DPI})$ 
Field photographs showing: (a) a general view of the lower part of the Garitas section, horizontal heterolithic stratification; (b) a detail of $A$, showing blackish (A1) rich in organic matter levels; (c) a phosphorite rich organic matter with shark teeth (fossil-bearing level A1); (e) the beige marl and siliceous limestone with Neptunian dykes in (f). 

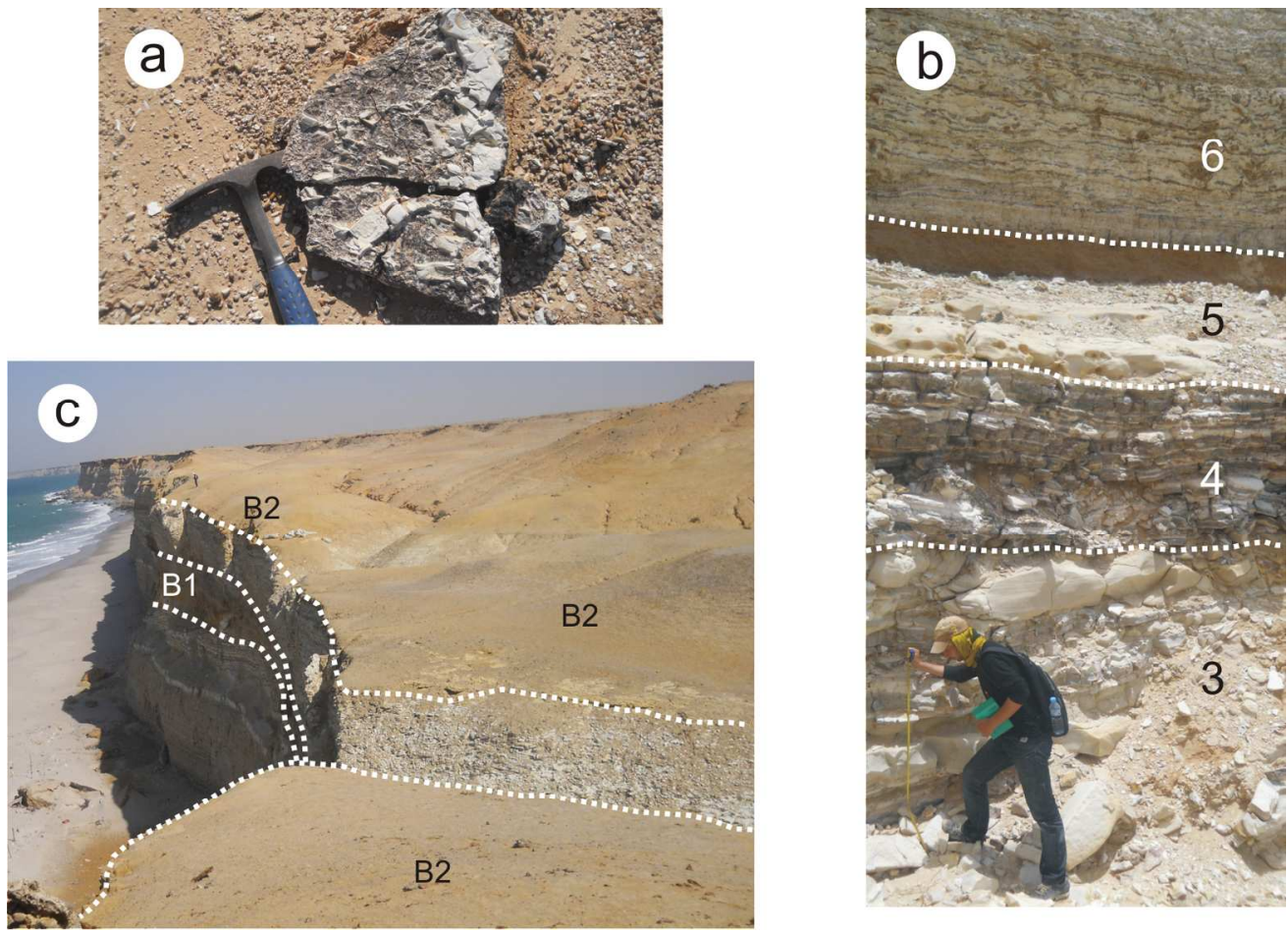

Field photographs showing: (a) an example of coprolite level; (b) a succession of gray limestone bar and beige sandy calcareous marl (lithofacies 3 in figure 2), black to brown or dark siliceous limestone with coprolites at its base (lithofacies 4), yellowish sandy marl rich in vertebrate fossil, fossil-bearing level B1 (lithofacies 5); (c) a whitish marl with lenticular brown siliceous limestone (lithofacies 6). 


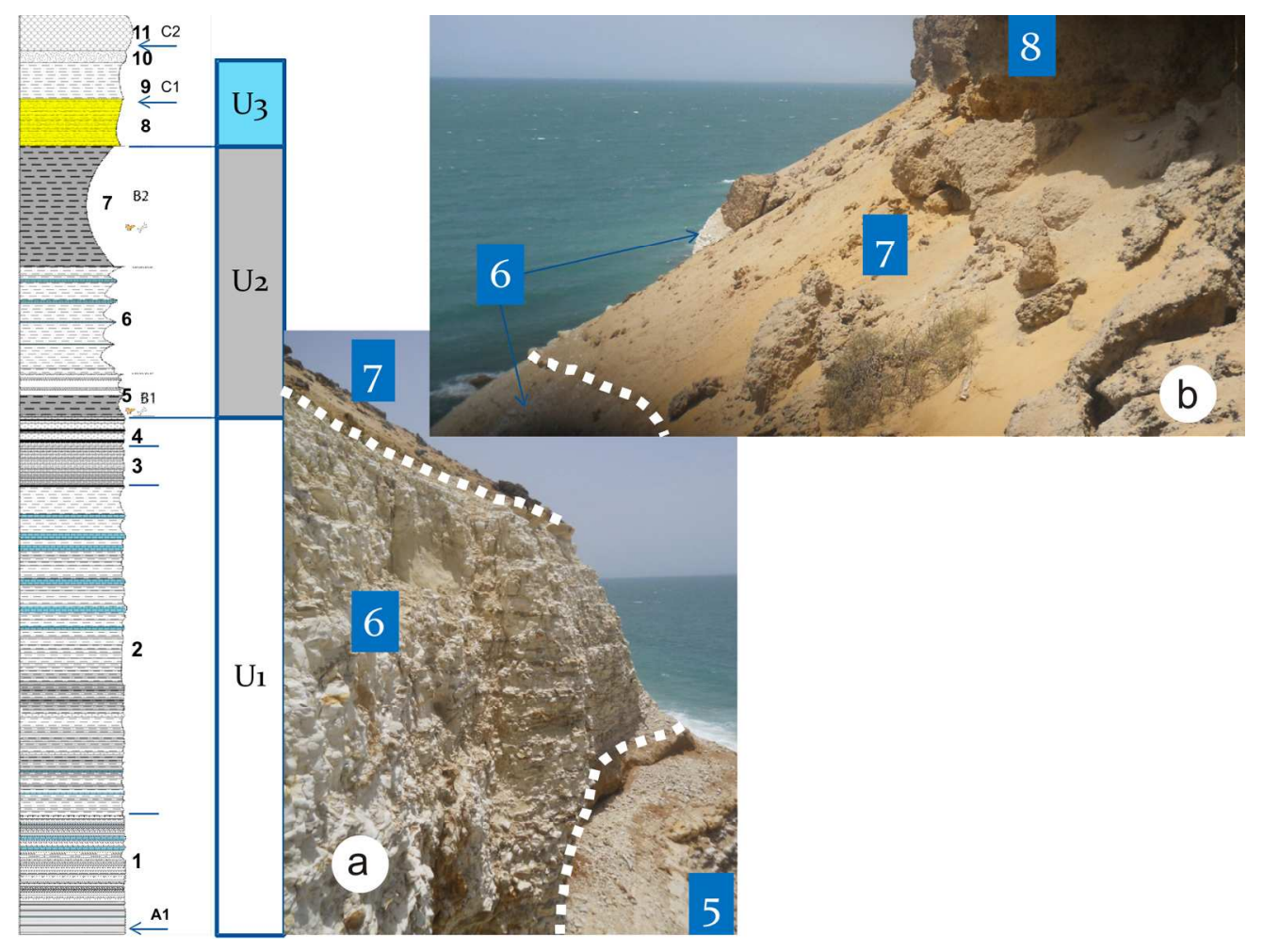

Garitas section. (a) lithofacies 6 forms the prominent ledge; (b) overlaying muddy brown yellow sandstone corresponding to fossil-bearing level B2 (lithofacies 7).

$$
173 \times 130 \mathrm{~mm}(300 \times 300 \text { DPI) }
$$




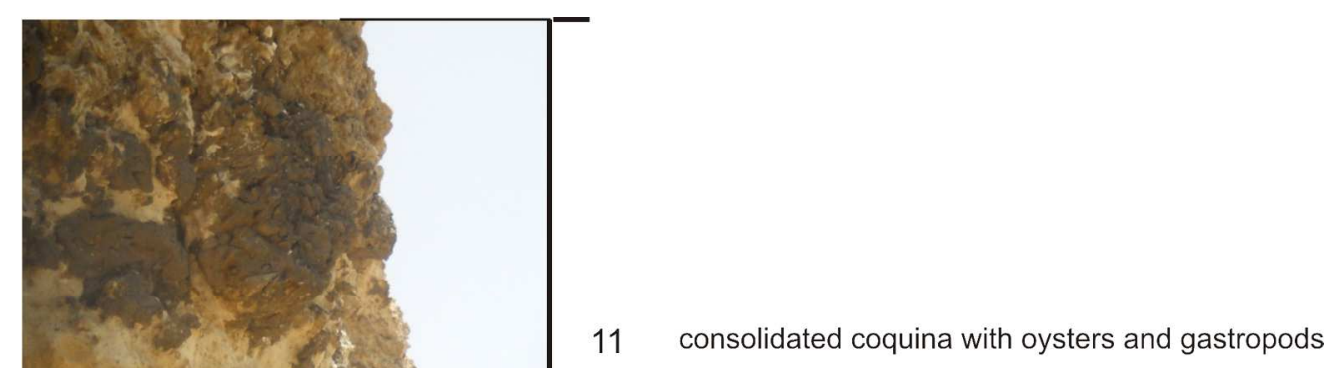

10 Red Sands

9 Beige sandy marls

Field photographs showing the top of the Garitas section with lithofacies 9, 10 and 11 . $169 \times 163 \mathrm{~mm}(300 \times 300$ DPI $)$ 

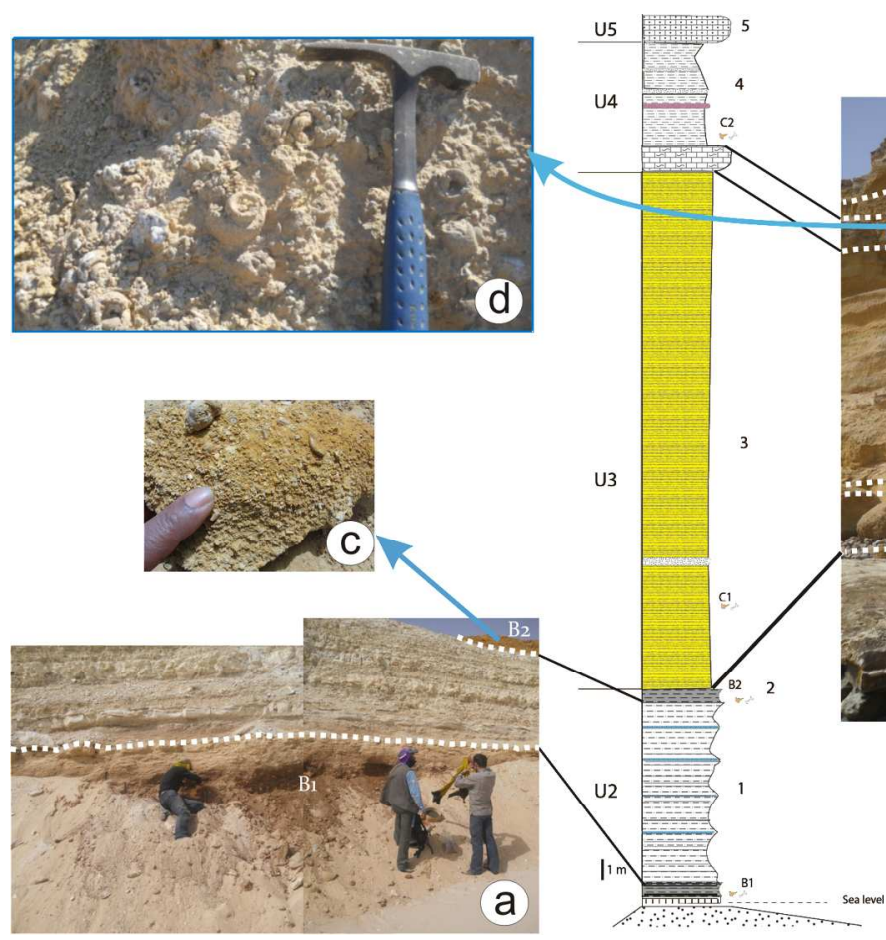

Porto Rico section. (a) general view of the lower part of the section with the fossil-bearing levels B1 and B2;

(b) exposure of the Unit U3 corresponding to the lithofacies 3, which consists of a thick multicolor sandy marl series interstratified by sandstone with limestone concretions (we can see the position of fossil-bearing levels C1 and C2); (c) photograph showing the abundant selachian teeth of the B2 level; (d) landmark level of gastropods and oysters coquina.

$170 \times 120 \mathrm{~mm}(300 \times 300$ DPI $)$ 


\begin{abstract}
field photographs and measured section of North Porto Rico and El Argoub areas. (a) section located $2 \mathrm{~km}$ north of El Argoub village, (b, c) sections is about $6 \mathrm{~km}$ north of Portorico. See the landmark level consisting of gastropod and oyster coquina at the lower part of $U 4$.
\end{abstract}

$167 \times 68 \mathrm{~mm}(300 \times 300 \mathrm{DPI})$ 


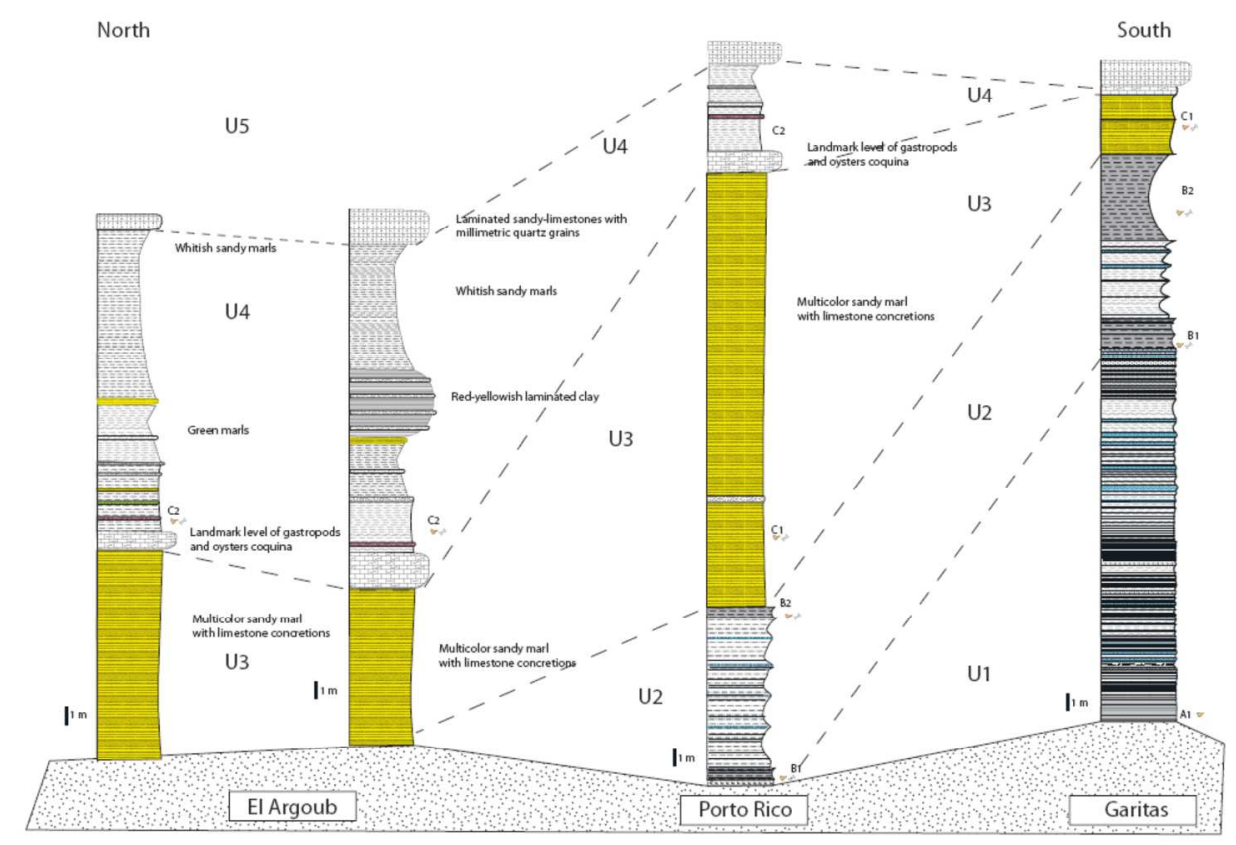

Outline correlation between cross sections from Garitas to El Argoub. $170 \times 119 \mathrm{~mm}(300 \times 300$ DPI $)$ 


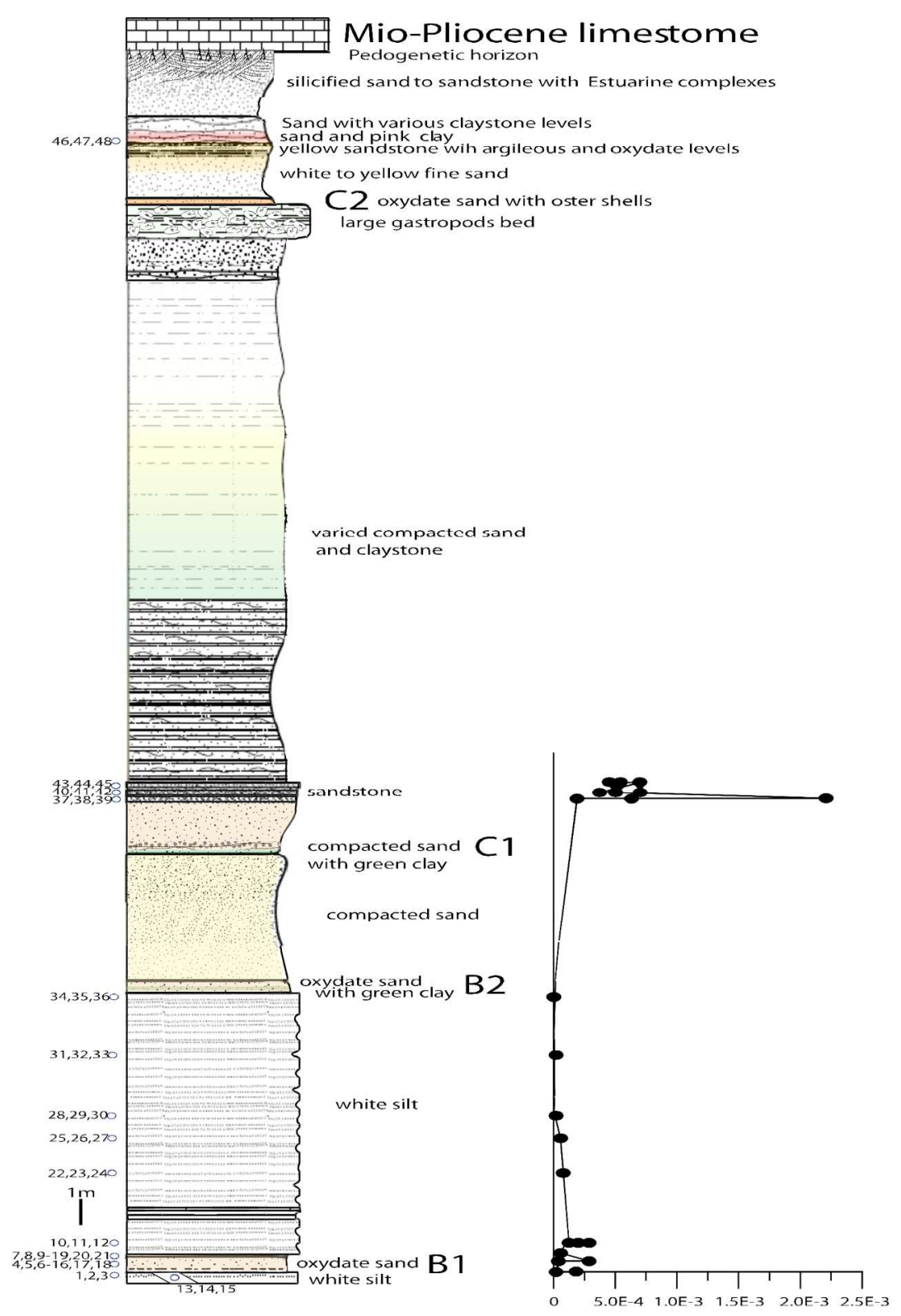

Porto Rico section and position of paleomagnetic sampling and the NRM intensities plotted against lithostratigraphic position (right curve). Note the position of the fossil-bearing B1, B2, C1 and C2. 

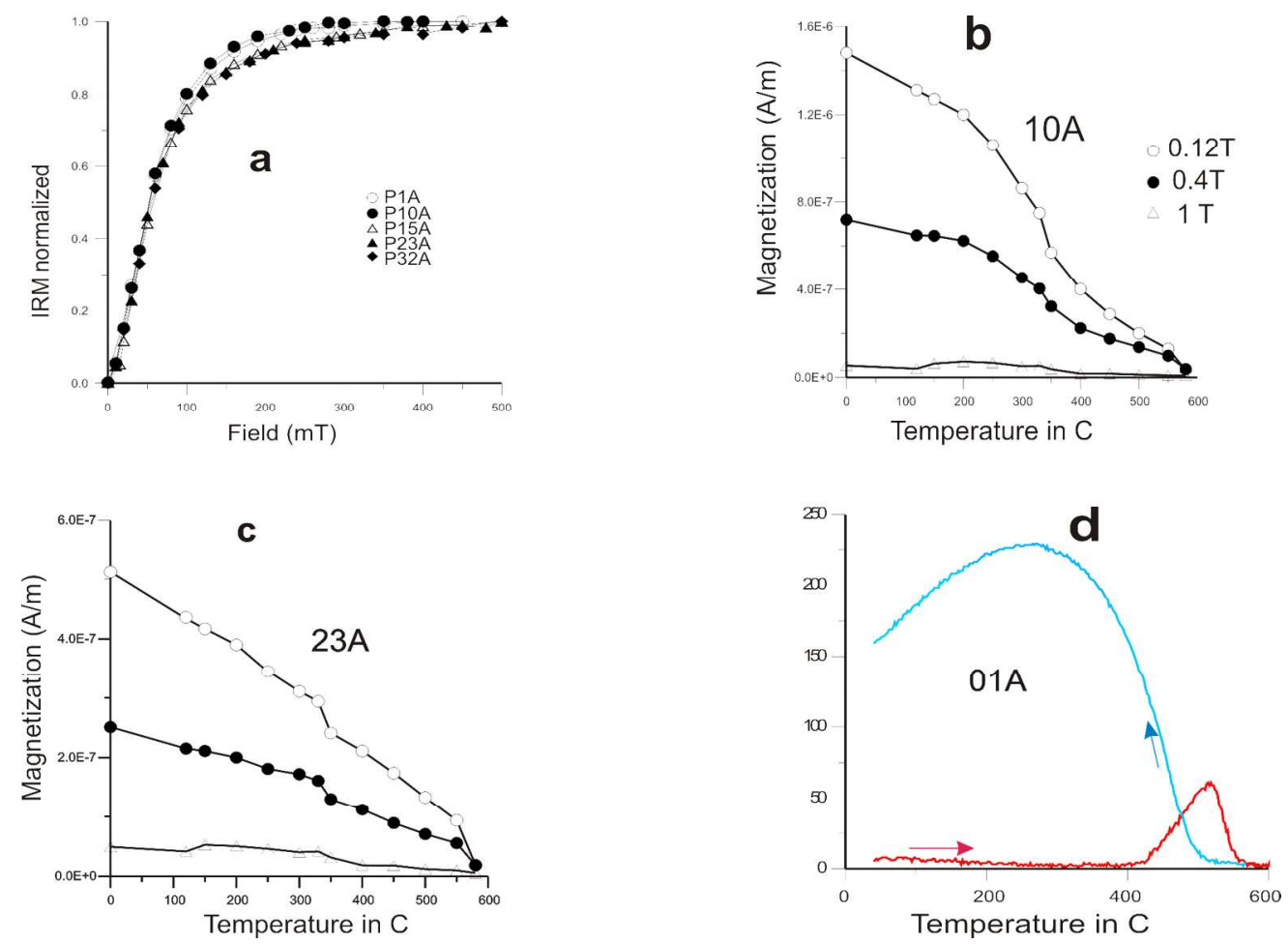

Paleomagnetic analysis: (a) acquisition of isothermal remanent magnetization (IRM) (normalized values) curves of same samples, with most of the magnetization acquired below $200 \mathrm{mT}$ and saturation achieved at $300 \mathrm{mT}$; (b, c) stepwise thermal demagnetization of the IRM components; (d) thermomagnetic curve of sample, where magnetic iron sulphides where suspected to be present in the samples. 

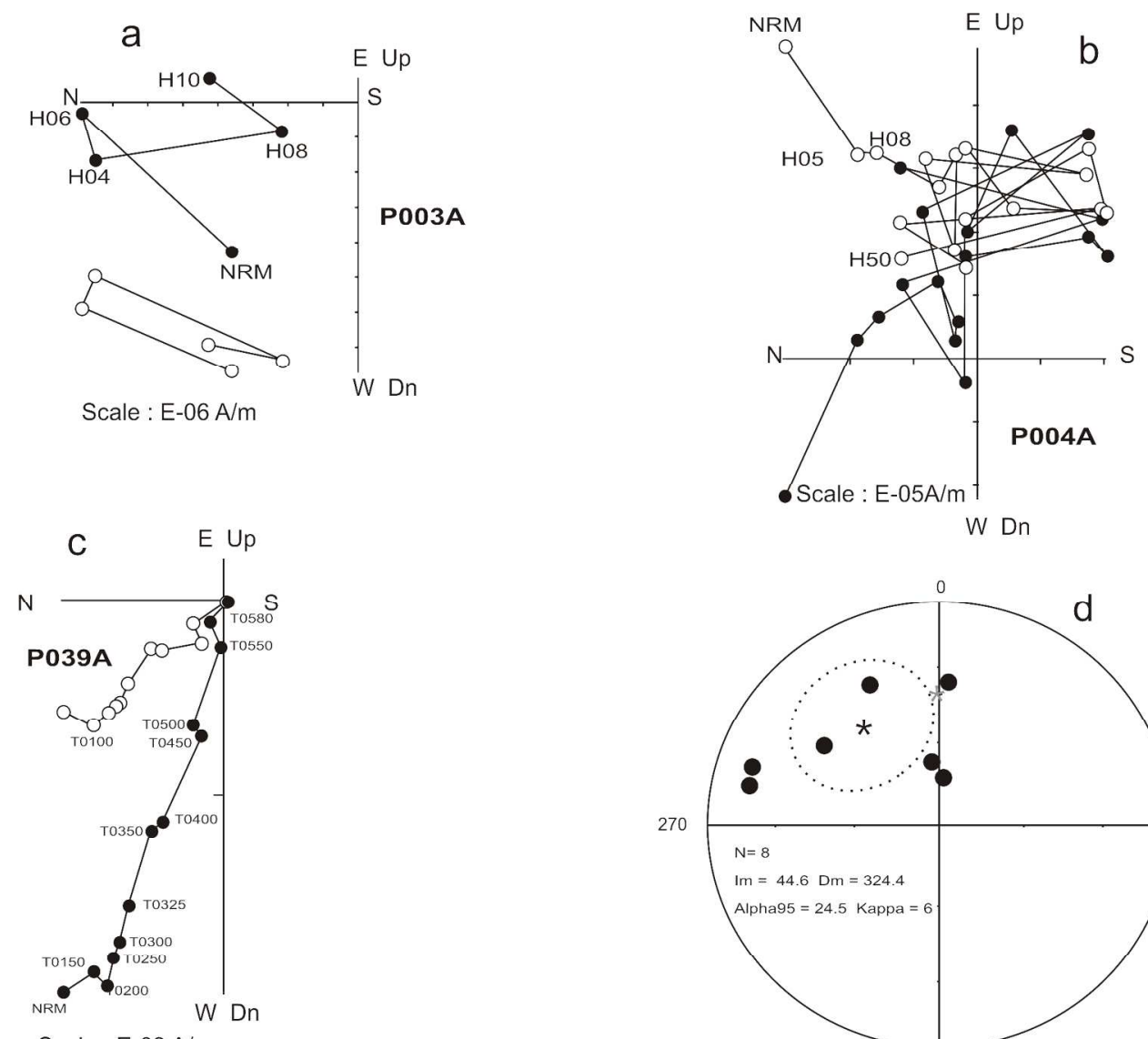

W Dn

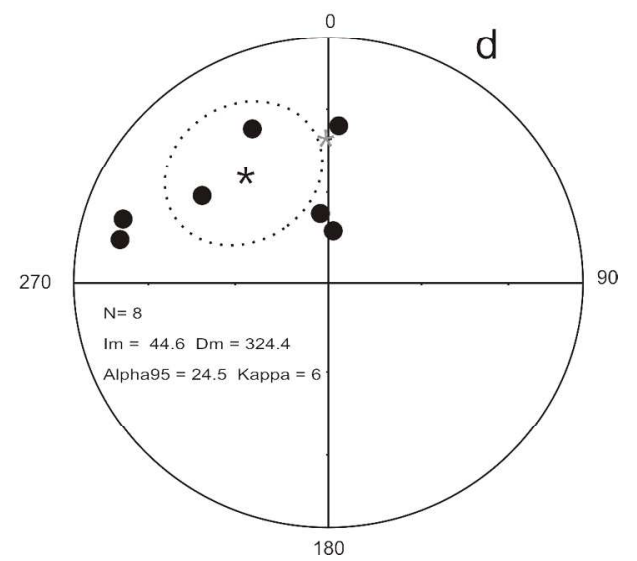

Demagnetization plots of the samples. The solid (open) symbols represent horizontal (vertical) projections, respectively. (a) at $10 \mathrm{mT}$, the magnetization intensity fall below the noise level of the magnetometer; (b) example of samples with erratic direction; (c) example of samples with normal polarity from the site situated $2 \mathrm{~m}$ above the $\mathrm{C} 1$ fossil-bearing level; (d) equal area projection and Fisher statistics of the reliable characteristic remanent magnetization (ChRM) direction. The 95\% confidence ellipse for the normal (solid star) mean directions is indicated (inclination $=44.6^{\circ}$, declination $=324.4^{\circ}$ ). Gray star is the geocentric axial dipole of the Porto Rico latitude.

$170 \times 152 \mathrm{~mm}(300 \times 300$ DPI $)$ 
Carbon isotope values (\%o VPDB) of the Porto Rico and El Argoub sections, compared to $\delta 13$ Ccurves around the Eocene-Oligocene transition in ODP Site 1218 (Erhardt et al., 2013) and reference $\delta 13 \mathrm{C}$ composite curve (Cramer et al., 2009 modified by Vandenberghe et al., 2012). EOT=Eocene-Oligocene Transition; U1 to U5 refer to the lithological units defined in the text. B1, B2, C1 and C2 are fossil-bearing levels. 


\begin{tabular}{|c|c|c|c|}
\hline section & label & $\mathrm{CaCO}_{3}(\%)$ & $\delta^{13} \mathrm{C}_{\text {org }}(\% \mathrm{n}$ VPD) \\
\hline \multirow[t]{25}{*}{ Porto Rico section } & PT015-18 & 0.0 & -25.2 \\
\hline & PTO15-17 & 0.0 & -23.7 \\
\hline & PTO15-16 & 0.0 & -25.4 \\
\hline & PTO15-15 & 0.0 & -24.7 \\
\hline & PTO15-14 & 0.0 & -24.6 \\
\hline & PT015-13 & 0.0 & -23.9 \\
\hline & PTO15-11 & 55.1 & -22.1 \\
\hline & PTO15-10 & 1.0 & -22.5 \\
\hline & РТO15-9 & 0.6 & -26.2 \\
\hline & PTO15-8 & 5.0 & -24.6 \\
\hline & PTO15-7 & 0.0 & -25.2 \\
\hline & PTO15-5 & 0.0 & -24.6 \\
\hline & PTO-41 & 2.0 & -25.6 \\
\hline & PTO15-4 & 0.0 & -25.0 \\
\hline & PTO15-3 & 0.0 & -25.8 \\
\hline & PTO15-2 & 1.2 & -24.3 \\
\hline & PTO-34 & 76.0 & -24.6 \\
\hline & PTO15-1 & 76.9 & -24.3 \\
\hline & PTO-32B & 1.0 & -24.4 \\
\hline & PTO-30B & 1.0 & -25.1 \\
\hline & PTO-26B & 1.0 & -24.9 \\
\hline & PTO-22B & 20 & -250 \\
\hline & PTO-21B & 59.0 & -25.1 \\
\hline & PTO-16B & 60.0 & -25.7 \\
\hline & PTO-2 & 43.0 & -27.6 \\
\hline \multirow[t]{11}{*}{ El Argoub section } & ARG15-12 & 0.0 & -25.5 \\
\hline & ARG15-11 & 0.0 & -25.4 \\
\hline & ARG15-10 & 1.4 & -23.0 \\
\hline & ARG15-9 & 1.3 & -25.7 \\
\hline & ARG15-8 & 0.0 & -25.1 \\
\hline & ARG15-7 & 1.0 & -25.0 \\
\hline & ARG15-6 & 3.2 & -24.2 \\
\hline & ARG15-4 & 45.3 & -245 \\
\hline & ARG15-3 & 28.7 & -23.4 \\
\hline & ARG15-2 & 0.0 & -27.8 \\
\hline & ARG15-1 & 0.5 & -24.2 \\
\hline \multirow{7}{*}{$\begin{array}{c}\text { Not analyzed (TOC too } \\
\text { low) }\end{array}$} & & & $T O C$ ton \\
\hline & $\begin{array}{l}\text { PT015-12 } \\
\text { PTO15-6 }\end{array}$ & $\begin{array}{c}41.2 \\
0.0\end{array}$ & $\begin{array}{l}\text { TOC too low } \\
\text { TOC too low }\end{array}$ \\
\hline & ARG15-5 & N.A. & TOC too low \\
\hline & PTO-43 & 3.0 & TOC too low \\
\hline & PTO-19 & N.A. & TOC too low \\
\hline & PTO-11 & 19.0 & TOC too low \\
\hline & PTO-5 & N.A. & TOC too low \\
\hline
\end{tabular}

\section{Sample labels, $\mathrm{CaCO} 3$ content (\%) and $\delta 13 \mathrm{Corg}$ values (\%o, VPDB); N.A. = not analyzed.}

